\section{Wealth sharing and peace processes}

\section{Achim Wennmann}

$\mathrm{D}$ eveloping wealth-sharing arrangements as part of a peace process can play an mportant role in conflict resolution. If disputes over the control of natural resources were factors in conflict onset, they can address a cause of conflict; if natural resources contributed to the financing of armed groups, they can help address the means of conflict and its perpetuation; and they can shape the framework for economic recovery and governance that support postconflict transitions. In this way, wealth-sharing arrangements are part of both backward-looking functions of peace processes that address the ends or means of past disputes and forward-looking functions that shape visions of a new society. ${ }^{1}$

Wealth sharing is often a part of power-sharing arrangements, the reconstitution of normal politics in a postconflict society through new institutional arrangements. ${ }^{2}$ Power sharing can shape the incentives belligerents face so that the benefits from participating in a government of national unity or autonomy arrangements are greater than challenging or overthrowing the state. Wealth sharing can be perceived by armed groups as a direct economic benefit and can increase commitment to a peace process by increasing the opportunity cost of continued conflict. It can resolve security dilemmas by balancing the relative gains between the parties to ensure that no party has the means to impose itself militarily. At the same time, power sharing confers responsibility to manage income sources through the shared control of institutions, and so can legitimize resource exploitation and facilitate mechanisms that regulate disputes over natural resources. ${ }^{3}$

How important income sharing is in a peace processes will likely depend on the architecture of the agreements, the priorities of the parties, and the revenue potential of natural resources. It is more important for comprehensive processes that regulate both the past conflict and frame future arrangements. Here the parties want to resolve the conflict and design alternative visions for society, including new economic arrangements. In a step-by-step peace processes, the emphasis is on ending the fighting, and income sharing is likely to be relegated to the postconflict period to reduce the complexity of cease-fire negotiations.

Understanding the circumstances behind the peace processes can provide important leads on the relative importance of income sharing. ${ }^{4}$ In particular, there has to be something left to share after the conflict. In both Sudan and Aceh, the resource base has been severely eroded: in Sudan, the most high-value oil will have been explored in Sudan by the end of the interim governance period between North and South in 2011; in Aceh, major oil companies will be closing facilities within a decade. In these circumstances, wealth sharing may only relate to finding fair agreements for the compensation of past exploitation.
Recent evidence on postconflict violence has emphasized the importance of nurturing alternative visions of societies during peace processes. Ensuring that the violence stops is important, but if combatants and populations do not have a notion of what comes next, some may think that their life during the conflict was more profitable and revert back to violent appropriation as a livelihood strategy. The results are criminalized parallel economies, or even full-scale renewal of fighting. Wealthsharing arrangements may therefore be crucial elements in managing war-to-peace transitions and making postconflict economic opportunities a more tangible prospect.

Recently there have been some suggestions that postconflict transitions can be consolidated by moving wealth sharing upstream into the peace process. This reflects a recognition of the transformative effects of armed conflict, and that economic recovery should start from what exists after a conflict rather then seeking to reconnect to some level of (imagined) preconflict development. Conflict economies are not simply a black box that represents an interruption of a linear process of economic development but rather the context for social and economic transformations. ${ }^{5}$

Thus, talking about natural resources in peace processes has the objective to prepare the ground for postconflict economic recovery and delineate an economic vision for the future. This entails creating employment opportunities and vocational training as well as stimulating private sector entrepreneurship. It also entails addressing extortion, protection, and monopolistic control, making nonviolent behavior more profitable, and increasing the opportunity cost of armed violence.

This article considers these issues by comparing the experiences of Sudan (North-South) and Indonesia (Aceh). It considers how the peace processes managed the natural resource element and investigates if and how the inclusion of such a dimension strengthened postconflict transitions. The concluding section draws lessons on what makes wealth sharing a more effective instrument for postconflict transitions.

\section{Sudan}

Sudan's Comprehensive Peace Agreement (CPA) of 9 January 2005 was a landmark deal to settle one of Africa's longest civil wars, between the Government of Sudan (GoS) and the Sudan People's Liberation Movement/Army (SPLM/A). ${ }^{6}$ It included agreements for an interim period from 2005 to 2011 on security, wealth sharing, power sharing, as well as on the three regions of Abyei, Southern Kordofan, and Blue Nile, and was hailed a model to resolve Sudan's other conflicts. Crucial future steps included elections in 2009 and a referendum on the future status of Southern Sudan in 2011. The Agreement on Wealth Sharing (AWS) of 7 January 2004 was one of six protocols that constituted the CPA. Wealth sharing became an issue in the peace process mainly because of the location of high-value oil wells in the border region between northern and southern Sudan. Oil represented "an incentive for peace in so far as oil activities could not be pursued in a war context.” Oil was part of a larger incentive structure for ending the conflict that contributed to tactically informed 
choices to relocate the fighting from the battlefield to the negotiation table.

The AWS is a comprehensive agreement that describes the sharing of resources and institutional arrangements for Sudan's postconflict economy in the interim period. Its preamble covers the division of oil and non-oil revenue, the management of the oil sector, monetary authority, and the reconstruction of the south and other war-affected areas. It establishes new institutions for the economic governance of north and south, including the National Land Commission (art. 2.6), the National Petroleum Commission (NPC) (art. 3.2), the Bank of Southern Sudan (art. 14.2), the Southern Sudan Reconstruction and Development Fund (art. 15.1), the National Reconstruction and Development Fund (art. 15.4) and the Multi-Donor Trust Funds (MDTFs) for Northern Sudan and Southern Sudan (art. 15.5).

While the agreement does not address the issues of ownership of natural resources, it specifies that the parties agree to resolve the issue at a later date (art. 2.1), and one of the main provisions is the sharing of net oil revenue from wells in Southern Sudan, according to a 50/50 formula, between the Government of Southern Sudan (GoSS) and the Government of Sudan (GoS) (art. 5.6), with at least two percent of oil revenue to be allocated to producing states or regions in proportion to their production (art. 5.5). Concerning non-oil revenue, the agreement specifies various sources of revenue collection for the GoS and the GoSS, including taxes and fees (art. 6). All national revenue is centralized in the National Revenue Fund (art. 7.1), with 50 percent of the revenue collected in Southern Sudan given to the GoSS (art. 7.3). With these provisions, the agreement organizes the economic governance and reconstruction of postconflict Sudan. Reaching an agreement on wealth sharing has been a major achievement of the peace process. Not only has oil been a major factor in the conflict's onset and dynamics; it also represents an indigenous source for the financing of postconflict recovery.

In the negotiations process toward the AWS, the parties managed to solve a number of critical problems. A deal on resource sharing was facilitated by allowing trade-offs in a single-text document; the deconstruction of complexities through the strategic use of resource persons; a compromise between debt service obligations and economic development needs; and changes in the payment modalities for oil exports. The decoupling of resource ownership and management prevented an early collapse of the negotiations. ${ }^{8}$

The AWS was, however, accompanied by various implementation problems associated with the lack of transparency of oil exploitation and trust between the National Congress Party and the SPLM/A, the absence of any full meetings of the NPC, and concerns about human and environmental consequences. Nevertheless, a first transfer to the GoSS of USD800 million reportedly occurred in February 2006, although this was over one year after the signing of the CPA and there was no indication of a reference period nor whether it corresponded to the 50/50 formula. By 2008, collaboration on wealth sharing had improved with the GoS being recognized to have paid arrears for the period 2005 to 2007. For 2007, GoSS revenue has been calculated to amount USD1,458 million, a not inconsiderable sum. Yet suspicions remained that this did not comply with the sharing formula. Independent verification of oil contracts with international firms, levels of oil exports, and price arrangements were not possible and prevented the

investigation of undeclared production, kickbacks, and corruption. Lack of progress in the demarcation of the North-South border also prevented the establishment of clear parameters to calculate oil wealth in the border areas. ${ }^{9}$

There are a number of reasons why the AWS did not lead to a more substantial peace dividend. The lack of prewar development and the duration and impact of the armed conflict had already been identified in 2005 as likely inhibiting factors for economic development. It also became apparent that the GoSS lacked capacity to systematically collect, store, manage, and allocate oil and non-oil revenue, and there were allegations that this also fostered corruption within the SPLM/A. In addition, the overall security and political context of Sudan was hardly an environment conducive for the AWS to unfold a constructive contribution to postconflict transition. While the CPA stopped the conflict between the GoS and SPLM/A, fighting escalated in Darfur and with Chad, while armed groups proliferated along different and changing alliances. Sudan also became increasingly militarized, with large-scale military assistance from China, increasing levels of weapons imports, and the development of an indigenous arms manufacturing industry. The monumental task of demobilizing and reintegrating about 180,000 ex-combatants has yet to be realized, and, as the United Nations Security Council (UNSC) stated, "the lack of mutual trust and confidence between the NCP and SPLM remains the main challenge for the implementation of the [CPA]." In October 2007, the SPLM even temporarily withdrew from the Unity Government. ${ }^{10}$

The partial treatment of water and land issues in the AWS also created problems. Water issues were not a primary interest of the GoS and GoSS and their inclusion would have extended the peace processes to Sudan's neighbors, which would in turn have complicated negotiations. Furthermore, the AWS only included land issues in vague terms as part of the Land Commission. The inability to systematically address land rights underlines the continued existence of unresolved local conflicts that have been exacerbated by population movements and environmental changes. ${ }^{11}$

A significant decline in the deposits of high-quality oil wells in the south pose a challenge to the future viability of Southern Sudan. The occurrence of oil-particularly the most commercially viable AAA oil-is concentrated in the Abyei region and the Melut basin in eastern Sudan, and production and pipeline construction has focused on these areas. It is estimated that more than half of the 
reserves in Abyei have been exploited while the Melut basin remained largely untapped by 2006. Abyei's declining production is believed to be the result of a GoS policy to extract as much as possible prior to the referendum in 2011. However, lack of transparency makes it impossible to verify these allegations. These developments have clear implication for the significance and functions of resource sharing in a future peace process. ${ }^{12}$

In the final analysis, the AWS was unable to secure immediate post-agreement peace dividends. While the GoSS did receive oil revenue, its lack of capacity to plan, allocate, and spend these resources limited its contribution to economic recovery. However, these observations need to be measured against the objectives and possibilities of the AWS and the peace process. The CPA was the outcome of a process in which the GoS and SPLM/A continued to fight by other means and so reflected short-term military, political, and economic interests, and its problems reflected “the parties' mistrust, self-interest, and ambiguous agendas and a lack of any shared commitment to addressing the country's key problems and building a common future.” In this context, the peace process was never designed, nor mandated, to negotiate outside the bounds of what was perceived as acceptable by the parties. The AWS emerged from interests converging on oil revenue rather than from creating sustainable economies or addressing Sudan’s multiple disputes. ${ }^{13}$

\section{Aceh}

The conflict in Aceh is often portrayed as a classic secessionist conflict, involving a relatively homogenous population that took up arms in response to military oppression and economic exploitation. ${ }^{14}$ It has also been considered a classic resource conflict in which oppressive natural resource exploitation paralleled by local impoverishment created grievances that fanned a pre-existing conflict about self-determination. The discovery of natural gas in northeastern Aceh in 1974 was a central factor in the origin and evolution of civil war. Gas extraction intensified the government's appropriation of revenues, contributed to Aceh's economic decline, and resulted in an increased military presence to protect the gas fields. Three decades of armed conflict ended in 2005 after Aceh had been severely affected by a tsunami. Prior to the natural disaster, the conflict parties had started exploring a negotiated settlement. The Memorandum of Understanding (MoU) of 15 August 2005 closed one of Asia's longest-running civil wars and framed Aceh's postconflict and tsunami recovery. ${ }^{15}$

Systematic attempts at negotiated settlements only developed after the fall of President Suharto who ruled Indonesia from 1967 to1998. In 2000, the Geneva-based Center for Humanitarian Dialogue led the first-ever peace initiative between the Gerakan Aceh Merdeka (GAM, or Free Aceh Movement) and the government, leading to a Humanitarian Pause in 2000 and a cease-fire agreement in 2002. In Jakarta, however, the government was sharply criticized over what seemed to be an international recognition of the GAM. Meanwhile, President Sokarnoputri ratified the
Law on Special Autonomy for the Province Naggro Aceh Darussalam (hereafter, "the NAD law”) in August 2001, providing unprecedented powers of self-governance and control over natural resources in exchange for cessation of hostilities and the renunciation of independence. It set out a series of provisions on, for example, the enforcement of aspects of Islamic law, direct elections of Acehnese regional representatives and new institutions. A central aspect was that Aceh would receive 70 percent of the revenues generated from Aceh's rich oil and gas fields, with the remaining 30 percent going to the central government. After an 8-year period this share would be equalized to 50 percent each. The government claimed that the special autonomy law was much more generous than previous legal provisions, allowing for an 80 percent retainer from income deriving from natural gas, fishing, general mining and forestry. ${ }^{16}$

Even if engaging on paper, the NAD law had many limitations as a wealth-sharing tool. It failed to realistically address Aceh's economic grievances and prospects and, most importantly, to build local confidence in the government's commitment to its implementation. It neither included baseline assessments on economic reserves nor specific modalities of revenue sharing and gave no consideration to Aceh's economic prospects once reserves have been depleted. It was also unclear if the oil and gas revenues referred to the total production in the province, or simply part of it. In addition, that revenue would first be collected by Jakarta and then be disbursed to local officials fueled suspicions that payments were intended as political tools. This resulted in the NAD law being received unfavorably in Aceh. The revenue-sharing provisions were perceived as a means to provide incumbent political elites with additional opportunities for corruption. Even if some government officials presented the NAD law as a flexible starting point, the complete omission of political representation, the lack of reduction of Jakarta's military presence, and lack of investigation into past atrocities fanned the perception that it was a ploy. The law was also conceived without any input by the GAM or Acehnese civil society, and was therefore devoid of any ownership. Consequently, GAM rejected the NAD law, a decision that echoed a widespread lack of grassroots support and a prevailing mistrust against Jakarta. ${ }^{17}$

In contrast, the government portrayed the NAD law as a generous offer, which increased the scope for Parliament and TNI to pressure the government not to commit to any further compromises. ${ }^{18}$ For the government, the NAD law limited the room to manoeuver and complicated its negotiation position. Other political developments were also damaging. In 2003, President Sukarnoputri deployed a multi-track strategy against the GAM that included the NAD law, diplomatic efforts against the GAM's international representations, secret back-channel contacts, and the continuation of military activities. Such a strategy enabled her to manage various constituencies, especially her backers in the military as well as the international community. The Indonesian military agreed with the law, but only under the assumption that the GAM would accept it as a final solution. Six months later, the military convinced 
Sukarnoputri to adopt a military strategy and create a new special military command for Aceh. This was the death stroke for the NAD law and its provisions of wealth sharing. The TNI's escalation of the conflict in 2003 undermined the GAM's belief that the special autonomy offer and wealth sharing had been made in good faith by the government. $^{19}$

The destruction caused by the tsunami and the subsequent humanitarian and development investments makes it difficult to isolate the effect of the absence of a more detailed treatment of wealth sharing. The Memorandum of Understanding (MoU) of 15 August 2005 only makes reference to a principal agreement: “Aceh is entitled to retain seventy per cent of the revenues from all current and future hydrocarbon deposits and other natural resources in the territory of Aceh as well as in the territorial sea surrounding Aceh” (art. 1.3.4). However, the lack of precision of wealth sharing in the MoU has been said to complicate its implementation. The MoU does not "mention who will regulate and govern [hydrocarbon revenue sources], or who has the authority to give licences for new explorations. The LOGA says only that the central and Aceh governments will manage the resources jointly. We should have made it right in the MoU."20

The overall significance of wealth sharing in Aceh's postconflict and tsunami transitions has also been questioned. Production peaked during the 1990s, and "oil and gas is almost finished.” ExxonMobil forecast that oil production in Aceh would end by 2011 and estimates that 90 percent of recoverable gas reserves are depleted, with an expected closure of gas fields in 2016. Due to the decline in gas reserves at the Arun fields, ExxonMobil and Pertamina closed two LNG fields in April 2000. And due to the rapidly depleting oil and gas reserves, Aceh's economy even contracted by 5.8 percent in the first half of 2008, a trend which is expected to continue in 2009. ${ }^{21}$

Thus the role of addressing wealth sharing in the peace process must also be placed in the context of the relative overall importance of oil and gas in Aceh's economy. While in the 1970s they were a driver of the conflict and a curse, the declining resource pool and possible closure of production facilities by the next decade substantially reduces their relative importance. During the peace process, wealth sharing was unable to contribute to a forward-looking perspective to the peace process because the government failed to present it as a credible option of conflict resolution, as a basis for a new economic vision for Aceh. In addition, wealth-sharing provisions of the NAD law had important shortcomings concerning sharing modalities and ownership.

\section{Conclusions}

Wealth-sharing arrangements can be an important part of conflict resolution, addressing major obstacles to peace and postconflict reconstruction. However, simply addressing the natural resource dimension in peace agreements provides no magic solution for problems in postconflict transitions. This is clear in the case studies of
Sudan and Aceh which, while reflecting rather different experiences, both illustrate that the fate of postconflict transitions depend on so many factors that focusing exclusively on the management of natural resources is unlikely foster long-term development yields. Broader political and military peacebuilding strategies are required, within which wealth-sharing arrangements should be an important component.

The case studies suggest important lessons on how to make wealth sharing a more effective instrument for postconflict transitions. The experience of Aceh shows that it is important to clearly define what is shared, and how to prevent misunderstandings during the peace process and postconflict implementation. Both countries illustrate the value of creating information on the future prospects and value of natural resources to level the playing field and manage expectations, particularly given that information about the occurrence and value of natural resources is often unreliable and scarce after years of conflict. This also means that negotiations need to remain flexible enough to allow resource ownership to remain unresolved in order to enable an agreement on revenue sharing.

Wealth-sharing negotiations need to be as inclusive as possible. The ownership of wealth-sharing arrangements is an important element for them to make a lasting contribution to a peace process. However, the lack of inclusiveness of the CPA increased frustrations of marginalized communities. Crucial for the mediator is to recognize the "sufficient" inclusion of supporters for deal-makers that marginalize spoilers. $^{22}$

Finally, negotiations on income sharing can shift relations between the parties from the emotive to the rational. Interests in revenue sharing can represent an incentive that overrides intergroup or personal animosities.

A practical problem for addressing natural-resource management in peace processes remains the operational distinction between conflict and postconflict phases. This distinction defines institutional mandates in the transition from war to peace. While political and security issues usually concern the United Nations, economic issues fall within the mandate of the international financial institutions such as the International Monetary Fund, the World Bank Group, or regional international economic organizations. In the case of El Salvador's peace process in the early 1990s, this disconnect has been compared to a patient lying "on the operating table with the left and right sides of his body separated by a curtain and unrelated surgery being performed on each side.” While much has been improved in interagency coordination since then, there remains a scope to foster integrated approaches that bridge the conflict/postconflict divide, and recognize the continuities and transformations in warto-peace transitions. ${ }^{23}$

\section{Notes}

Achim Wennmann is at the Center on Conflict, Development, and Peacebuilding, 
(C) www.epsjournal.org.uk - Vol. 5, No. 2 (2010)

Graduate Institute of International and Development Studies, Geneva. He may be reached at achim.wennmann@graduateinstitute.ch. This article is a revised version of a paper presented at the Thirteenth Annual International Conference on Economics and Security, Thessalonika, Greece, June 2009. It is a condensed version of Achim Wennmann "Wealth Sharing from Natural Resources in War-To-Peace Transitions," in Päivi Lujala and Siri Aas Rustad, eds. High-Value Natural Resources and Post-Conflict Peacebuilding. London: Earthscan (forthcoming, 2011). The article also draws on chapter 4 of the author's book The Political Economy of Peacemaking (London: Routledge. Forthcoming, 2010).

\section{Zartman (2005).}

2. These can include different degrees of autonomy, or consociational or integrative governance arrangements. Consociationalism is based on collaborative decisionmaking of different ethnically defined groups. An integrative approach seeks to build multiethnic coalitions surrounding issues in order to integrating society (see Sisk, 2003, p. 141).

3. Siriam (2008, pp. 25, 182); Hartzell (1999, p. 10).

4. Initial circumstances can include for example changes of the international context that foster initiatives to end the conflict through a comprehensive peace process (Guatemala, El Salvador, Mozambique) and international outrage over humanitarian consequences and human rights abuses that define pressures to end the fighting through a step-by-step process (Sierra Leone, Liberia, Afghanistan) (see Suhrke, et al., 2007, p. 31). Although wealth and income sharing are not the same thing, for the purposes of this article no differentiation is made.

5. Preconflict: UNDP (2008, pp. xix-xx); transformations: Cramer (2006, p. 197); Cramer (2009); Wennmann (2009a, p. 81).

6. This case study is based on Wennmann (2009b).

7. Quote: Batruch (2004, pp. 159-160); relocation: Wennmann (2009b, pp. 11-13).

8. Wennmann (2009b, pp. 14-17).

9. Environmental consequences: UNSC (2007, p. 4); arrears paid: UNSC (2008, p. 5); 2007 GoSS revenue: SMF (2008); independent verification: ICG (2008, p. 13); borders: ICG (2006, p. 7).
10. Inhibiting factors: Bude (2005, pp. 35-36); lack of governance capacity: ICG (2006, p. 8); corruption allegations: Jooma (2007, p. 12); Darfur/Chad: SAS (2007, pp. 320-326); indigenous arms industry: HSBA (2007a, p. 6); HSBA (2007b, pp. 4-6); ex-combatants: IRIN (2008); UNSC: UNSC (2008, p. 15).

11. Water: Rogier (2005, p. 41); Shafer (2007, pp. 6-8); land: Jooma (2005, p. 14); land rights: IISS (2007, p. 263).

12. Melut basin untapped: ECOS (2008, pp. 22); ICG (2007, p. 9); lack of transparency: ICG (2008, p. 13).

13. Quote: Rogier (2005, p. 41).

14. This section is based on Wennmann and Krause (2009).

15. Pre-existing conflict: Robinson (1998, p. 135); Sukma (2004, pp. 3-6); Reid (2006, pp. 4-6); economic decline: Ross (2005, p. 47).

16. Sharply criticized: Aspinall and Crouch (2003, p. 16); NAD: Miller (2006, p. 301); generous: Department of Foreign Affairs, Republic of Indonesia (2001); ICG (2001, pp. 6-10).

17. Economic prospects: ICG (2001, p. 8); oil and gas revenue: Martin (2006, p. 82); collected by Jakarta: ICG (2001, p. 8); ploy: Aspinall and Crouch (2003, p. 26); lack of grassroots support: Miller (2006, p. 304).

18. TNI is Tentara Nasional Indonesia, the Indonesia Defense Force.

19. Compromises: Huber (2004, p. 47); multi-track strategy: Schulze (2006, pp. 262-262); new military command: Jemadu (2006, p. 281); good faith: Aspinall (2005, p. 18); Wennmann and Krause (2009, p. 15).

20. Lack of precision: Yusuf (2007); quote: Yusuf, c.f. Large and Aguswandi (2008b, p. 81). LOGA is the Law of Governing on Aceh.

21. Quote: Yusuf (2007); expected closure: Indonesia Relief (2005); EIA (2007);World Bank (2008); LNG fields closed: Tse (2000, p. 2); contracting economy: World Bank (2008).

22. Darby (2001, p. 119). 
(C) www.epsjournal.org.uk - Vol. 5, No. 2 (2010)

23. International financial organizations: O’Donnell and Boyce (2007, p. 2); quote: de Soto and del Castillo (1994, p. 76).

\section{References}

Aspinall, E. 2005. “The Helsinki Agreement: A More Promising Basis for Peace in Aceh?” Washington, D.C.: East-West Center Washington.

Aspinall, E., and H. Crouch. 2003. "The Aceh Peace Process: Why it Failed.” Washington, D.C.: East-West Center Washington

Batruch, C. 2009. "Lundin Petroleum AB's Experience in East Africa: The Role of the Private Sector in Conflict-Prone Countries.” The Economics of Peace and Security Journal, vol. 5, no. 2 (this issue).

Batruch, C. 2004. “Oil and Conflict: Lundin Petroleum’s Experience in Sudan,” pp. 148-160 in A.J.K. Bailes and I. Frommelt, eds., Business and Security: Public-Private Sector Relationships in a New Security Environment. Oxford: Oxford University Press.

Bude, B.Y. 2005. "Peace Dividend and the Millennium Development Goals in Southern Sudan.” Sudan Economy Research Group Discussion Paper No. 36. Bremen: University of Bremen.

Cramer, C. 2009. “Trajectories of Accumulation through War and Peace,” pp. 139140 in R. Paris and T.G. Sisk, eds., The Dilemmas of Statebuilding: Confronting the Contradictions of Postwar Peace Operations. London: Routledge, London.

Cramer, C. 2006. Civil War is not a Stupid Thing: Accounting for Violence in Developing Countries. London: Hurst.

Darby, J. 2001. The Effects of Violence on Peace Processes. Washington, D.C.: United States Institute of Peace Press.

De Soto, A., and G. del Castillo. 1994. “Obstacles to Peacebuidling.” Foreign Policy, vol. 94, pp. 69-83.

[ECOS] European Coalition on Oil in Sudan. 2008. "Whose Oil? Sudan's Oil Industry.” Utrecht: IKV Pax Christi.

Department of Foreign Affairs, Republic of Indonesia. 2001. Special Autonomy Law in Nanggroe Aceh Darussalam (NAD) Law No. 18 of 2001. Directorate General for Socio-Cultural Relations and Foreign Information, Department of Foreign Affairs Republic of Indonesia. http://www.kbri-canberra.org.au/s_issues /aceh/aceh_specautonomy.htm [accessed 11 December 2008].

Hartzell, C.A. 1999. "Explaining the Stability of Negotiated Settlements to Intrastate Wars.” Journal of Conflict Resolution, vol.43, no.1, pp. 3-44.

[HSBA] Human Security Baseline Assessment. 2007a. "The Militarization of Sudan: A Preliminary Review of Arms Flows and Holdings.” Sudan Issue Brief No. 6. Geneva: Small Arms Survey.

[HSBA] Human Security Baseline Assessment. 2007b. "Arms, Oil and Darfur: The Evolution of Relations between China and Sudan.” Sudan Issue Brief No. 7.
Geneva: Small Arms Survey.

Huber, K. 2004. "The HDC in Aceh: Promises and Pitfalls of NGO Mediation and Implementation.” Washington D.C.: East-West Center Washington.

[ICG] International Crisis Group. 2008. "Sudan’s Comprehensive Peace Agreement: Beyond the Crisis.” Nairobi and Brussels: ICG.

[ICG] International Crisis Group. 2007. "Sudan: Breaking the Abyei Deadlock." Nairobi and Brussels: ICG.

[ICG] International Crisis Group. 2001. “Aceh: Can Autonomy Stem the Conflict?” Jakarta and Brussels: ICG.

[IISS] International Institute for Strategic Studies. 2007. Strategic Survey 2007. London: IISS.

[IRIN] Integrated Regional Information Network. 2008. "Preparing for Massive Demobilisation.” 21 October 2008. http://allafrica.com/stories/ 200810210681.html [accessed 3 November 2008].

Jemadu, A. 2006. "Democratization, the Indonesian Armed Forces, and Resolving the Aceh Conflict,” pp. 272-291 in A. Reid, ed. Verandah of Violence: The Background to the Aceh Problem. Singapore: Singapore University Press.

Jooma, M. 2007. "Dual Realities: Peace and War in Sudan-An Update of the Implementation of the CPA.” Situation Report. 16 May 2007. Pretoria: Institute for Security Studies.

Jooma, M. 2005. "Feeding the Peace: Challenges Facing Human Security in Post-Garang South Sudan.” Situation Report. 23 August 2005. Pretoria: Institute for Security Studies.

Large, J. and Aguswandi, eds. Reconfiguring Politics: The Indonesia-Aceh Peace Process. London: Conciliation Resources.

Martin, H. 2006. Kings of Peace, Pawns of War: The Untold Story of Peace-Making. London: Continuum.

Miller, M.A. 2006. “What's Special about Special Autonomy in Aceh?” pp. 292-314 in A. Reid, ed. Verandah of Violence: The Background to the Aceh Problem. Singapore: Singapore University Press.

O’Donnell, M. and J.K. Boyce. 2007. Peace and the Public Purse: Economic Policies for Postwar Statebuilding. Boulder, CO: Lynne Rienner.

Reid, A. 2006. "Introduction,” pp. 1-20 in A. Reid, ed. Verandah of Violence: The Background to the Aceh Problem. Singapore: Singapore University Press.

Rogier, E. 2005. "Designing an Integrated Strategy for Peace, Security and Development in Post-Conflict Sudan.” The Hague: Netherlands Institute of International Relations Clingendael.

Robinson, G. 1998. "Rawan is as Rawan Does: The Origins of Disorder in New Order Aceh.” Indonesi, vol. 66, pp. 126-157.

Ross, M.L. 2005. "Resources and Rebellion in Aceh, Indonesia,” pp. 35-38 in P.Collier and N. Sambanis, eds. Understanding Civil War. Vol. II: Europe, Central Asia, and other Regions. Washington D.C.: World Bank. 
(C) www.epsjournal.org.uk - Vol. 5, No. 2 (2010)

Schulze, K.E. 2006. "Insurgency and Counter-Insurgency: Strategy and the Aceh Conflict-October 1976-May 2004,” pp. 225-271 in A. Reid, ed. Verandah of Violence: The Background to the Aceh Problem. Singapore: Singapore University Press.

Shafer, L.A. 2007. “Negotiating the North/South Conflict: Sudan's Comprehensive Peace Agreement.” Paper 148. Pretoria: Institute for Security Studies.

Siriam, C.L. 2008. Peace as Governance: Power Sharing, Armed Groups, and Contemporary Peace Negotiations. Houndsmills, U.K.: Palgrave Macmillan.

Sisk, T.D. 2003. "Power Sharing After Civil Wars: Matching Problems to Solutions," pp. 139-150 in J. Darby and R. MacGinty, eds., Contemporary Peacemaking: Conflict, Violence and Peace Processes. Houndsmills, U.K.: Palgrave Macmillan.

[SMF] Sudan Ministry of Finance. 2008. "Template for Publication of Sudan Oil Sector Data 2007.” http://www.ecosonline.org/back/pdf_reports/2008/Sudan\% 20production\%20and\%20exports\%20by\%20blend_2007_MOF.pdf [accessed 1 November 2008].

Sukma, R. 2004. "Security Operations in Aceh: Goals, Consequences, and Lessons.” Washington, D.C.: East-West Center Washington.

Suhrke, A., T. Wimpelmann, and M. Davis. 2007. "Peace Processes and Statebuilding: Economic and Institutional Provisions of Peace Agreements.” Bergen, Norway: Chr. Michelsen Institute.

Tellness, J. 2005. "Dealing with Petroleum Issues in Civil War Negotiations: The Case of Sudan.” Paper presented at the 13th Annual National Political Science Conference. 5-7 January 2005. Hurdalssjøen.

Tse, P.-K. 2000. “The Mineral Industry of Indonesia: United States Geological Survey Mineral Yearbook 2000.” http://minerals.er.usgs.gov/minerals/pubs/ country/ 2000/9313000.pdf. [accessed 19 December 2008].

[UNDP] United Nations Development Programme. 2008. Post-Conflict Economic Recovery: Enabling Local Ingenuity. New York: UNDP.

[UNSC] United Nations Security Council. 2008. Report of the Secretary-General on Sudan. Document S/2008/662. New York: United Nations.

Wennmann, A. 2009a. “Conflict Economies,” pp. 74-91 in Vincent Chetail, ed., Post-Conflict Peacebuilding: A Lexicon. Oxfrod: Oxford University Press.

Wennmann, A. 2009b. “Wealth Sharing Beyond 2011: Economic Issues in Sudan’s North-South Peace Process. CCDP Working Paper 1. Geneva: The Graduate Institute.

Wennmann, A. and J. Krause. 2009. "Managing the Economic Dimensions of Peace Processes: Resource Wealth, Autonomy, and Peace in Aceh.” CCDP Working Paper 3. Geneva: The Graduate Institute.

World Bank. 2008. “Aceh Conflict Monitoring Update, 1st-30th September 2008.” Jakarta: World Bank.

Yusuf, I. 2007. “Q\&A with Aceh’s Governor Irwandi Yusuf.” AsiaSource. 13 September 2007. http://www.asiasource.org/news/special_reports/ acehgovernor.cfm [accessed 30 January 2007].

Zartman, I.W. 2005. "Looking Forward and Looking Backward on Negotiation Theory,” pp. 287-301 in I.W. Zartman and V. Kremenyuk, eds. Peace Versus Justice: Negotiation Forward- and Backward-looking Outcomes. Lanham, MD: Rowman and Littlefield. 